\title{
PARTISIPASI MASYARAKAT DALAM MUSYAWARAH PERENCANAAN PEMBANGUNAN DI KELURAHAN PALANGKA KOTA PALANGKA RAYA
}

\author{
Community Participation in Development Planning Deliberations \\ in Palangka Village, Palangka Raya City
}

\section{Masrukin* \\ Anwar}

Universitas Muhammadiyah Palangkaraya, Palangka Raya, Central Kalimantan, Indonesia

email:

\section{masrukin@umpalangkaraya.ac.id}

\section{Kata Kunci:}

Partisipasi Masyarkat

Musyawarah

Perencanaan

Pembangunan

\section{Keywords:}

Community Participation

discussion

Planning

Development

\section{Accepted \\ January 2017}

\section{Published}

April 2017

\begin{abstract}
Abstrak
Penelitian ini bertujuan untuk mengetahui, menjelaskan dan mendeskripsikan tentang partisipasi partisipasi masyarakat dalam musyawarah perencanaan pembangunan di Kelurahan Palangka Kota Palangka Raya.

Penelitian ini menggunakan metode penelitian kualitatif, penelitian yang dilakukan merupakan penelitian deskriptif diman partisipasi masyarakat dalam perencanaan pembangunan di Kelurahan Palangka Kota Palangka Raya dipilih sebagai lokasi penelitian. Tekhnik pengumpulan data dengan cara observasi, wawancara, dan dokumentasi.

Berdasarkan hasil penelitian dapat disimpulkan Sistem pembangunan di kelurahan palangka adalah suatu proses politik untuk memperoleh kesempatan bersama melalui aktivitas yang didalamnya terdapat negosiasi antar seluruh pelaku pembangunan. System pembangunan yang ada di kelurahan Palangka ini dilakukan secara transparan sehingga masyarakat memperoleh kemudahan dan mengetahui setiap proses pembangunan serta setiap tahap perkembangannya. Dalam hal ini lebih sebagai sebuah alat pengambil keputusan yang diharapkan dapat mengetahui apa yang menjadi kebutuhan masyarakat.
\end{abstract}

\section{PENDAHULUAN}

Musrenbang desa/kelurahan adalah forum musyawarah tahunan para pemangku kepentingan (stakeholder) desa/kelurahan untuk menyepakati rencana kegiatan untuk tahun anggaran berikutnya. Musrenbang desa/kelurahan dilakukan setiap bulan januari untuk menyusun rencana kegiatan tahunan desa dengan mengacu/ memperhatikan kepada rencana pembangunan jangka menengah desa (RPJM) yang sudah disusun.

Karangka Hukum Musrenbang Desa/Kelurahan berdasarkan Undang-undang NO2 tahun 2015 tentang pemerintah daerah merupakan karangka dasar otonomi daerah yang salah satunya mengamanatkan dilaksanakannya perencanaan pembangunandari bawah secara partisipasif. Peraturan pemerintah NO.72/2005 tentang desa menjabarkan lebih lanjut mengenai posisi 
desa dalam konteks otonomi daerah dengan mengacu pada UU NO 2/20I5 tersebut. Sedangkan kelurahan dijabarkan dalam peraturan pemerintah no.73/2005 tentang kelurahan.

Paradigma pembangunan di Indonesia pada awalnya menjadi tugas dan tanggungjawab pemerintah secara keseluruhan, dalam di arti kata, pemerintahlah yang berstatus sebagai pusat seluruh aktivitas pembangunan, baik dari segi penyusunan rencana, pelaksanaan dan pembiayaan pembangunan. Setelah aktivitas pembangunan dengan paradigma tersebut belum dapat membuahkan hasil yang optimal, salah satu faktor yang menjadi penghambat adalah besarnya dana pembangunan yang harus disiapkan oleh pemerintah, akibatnya paradigma tersebut mengalami perubahan, sehingga pembangunan yang dilakukan menjadikan masyarakat sebagai pelaksana terdepan pembangunan bangsa dan negara. Karena disadari oleh pemerintah bahwa hanya dengan menjadikan masyarakat sebagai obyek dan sekaligus sebagai subyek pembangunan yang memungkinkan tercapainya pembangunan

secara optimal. Atas dasar pertimbangan itulah sehingga partisipasi masyarakat dan Swasta dalam pembangunan senantiasa diupayakan untuk ditumbuhkan dan dikembangkan mulai dari masyarakat kelurahan sampai pada masyarakat kota.

Sistem adalah suatu cara yang mekanismenyaberpatron (berpola) dan konsisten, bahkanmekanismenya sering disebut otomatis. Sementara itu, Menurut Ghazali (2008:28) suatu system yang dibuat tentunya memiliki maksud tertentu, system yang di buat untuk mencapai suatu tujuan (goal) dan sasaran (objective). Tujuan biasanya dihubungkan dengan ruang lingkup yang lebih luas dan sasaran biasanya dalam ruang lingkup yang lebih sempit.

Syarat-syarat yang harus dimiliki system menurut Ghazali (2008:28) sebagai berikut :

I. System harus di bentuk untuk menyelesaikan suatu tujuan.
2. Elemen Sistem harus mempunyai rencana yang ditetapkan.

3. Adanya hubungan di antara elemen Sistem.

4. Unsure dasar dari Sistem (arus, informasi, energi, dan material)

5. Lebih penting dari pada elemen Sistem.

Untuk mencapai keberhasilan pembangunan tersebut, maka banyak aspek atau hal-hal yang harus diperhatikan, yang di antaranya adalah keterlibatan masyarakat di dalam pembangunan.Sanit (Suryono, 2001:32) menjelaskan bahwa pembangunan dimulai dari pelibatan masyarakat.

Ada beberapa keuntungan ketika masyarakat dilibatkan dalam perencanaan pembangunan, yaitu, Pertama, pembangunan akan berjalan sesuai dengan kebutuhan masyarakat. Artinya bahwa, jika masyarakat dilibatkan dalam perencanaan pembangunan, maka akan tercipta kontrol terhadap pembangunan tersebut. Kedua, pembangunan yang berorientasi pada masyarakat akan menciptakan stabilitas politik. Oleh karena masyarakat berpartisipasi dalam perencanaan pembangunan, sehingga masyarakat bisa menjadi kontrol terhadap pembangunan yang sedang terjadi.

\section{METODOLOGI}

Metode penelitian yang digunakan dalam penelitian ini adalah metode penelitian dengan menggunakan pendekatan kualitatif, di mana penelitian yang dilakukan bersifat deskriptif. Achmadi (2004:44) memberikan pengertian penelitian yang berusaha untuk menuturkan pemecahan masalah yang ada sekarang berdasarkan data-data, jadi ia juga menyajikan data, menganalis dan menginterpretasi, serta juga bisa bersifat komparatif dan korelatif.

\section{HASIL DAN PEMBAHASAN}

System pembangunan di kelurahan palangka dilakukan dalam rangka menyusun perencanaan pembangunan 
tahunan yang berupa daftar prioritas yang disampaikan dalam system yang lebih baik.

Berkaitan dengan yang peneliti temukan di lapangan banyak masyarakat yang mengeluhkan saat musrembang tidak diikutkan. Pir setiap RT mengajukan lebih dari satu pembangunan, banyak pengajuan masyarakat yang belum terkalisakan dalam kontek pembangunan. Partisipasi masyarakat disebagian RT yang ada dikelurahan Palangka Kecamatan Jekan Raya merasa kecewa karena pengajuan mereka banyak yang tidak di Acc dari pemerintah, masyarakat setempat menurut temuan yang saya dapat dilapangan mengeluhkan lembaganya waktu pembangunan yang ada di Kelurahan Palangka ini.

Masyarakat menyalahkan pihak kelurahan tidak mendengar aprisiasi dari masyarakat, padahal saya tau pihak kelurahan hanya menampung saja aspirasi masyarakat dengan cara dilakukannya musrembang. Semua masyarakat ikut diikutsertakan dalam musrembang yang bagaimana setiap masyarakat diwakili oleh setiap ketua RT/ ataupun RW masingmasing.

Dalam artian, masyarakat mengeluhkan kinerja pemerintah dalam pembangunan, tetapi disisi lain peneliti melihat langsung pemerintah kota kitabekerja sangat optimal semua pengajuan masyarakat sudah dikerjakan, walaupun masih ada saja yang belum terkalasikan. Faktor yang mempengaruhi keterlambatan pembangunan di Kelurahan Palangka adalah dari segi dana.

\section{KESIMPULAN}

Sistem pembangunan di Kelurahan Palangka adalah suatu proses politik untuk memperoleh kesempatan bersama melalui aktivitas yang didalamnya terdapat negosiasi antar seluruh pelaku pembangunan. Sistem pembangunan yang ada di Kelurahan Palangka ini dilakukan secara transparan sehingga masyarakat memperoleh kemudahan dan mengetahui setiap proses pembangunan serta setiap tahap perkembangannya.
Dalam hal ini lebih sebagai sebuah alat pengambil keputusan yang diharapkan dapat mengetahui apa yang menjadi kebutuhan masyarakat.

Melihat tingkat partisipasi masyarakat dalam pembangunan di Kelurahan Palangka yang kategorinya sedang, maka perlu adanya upaya upayaoleh pemerintah untuk merangsang masyarakat untuk berpartisipasi dalam pembangunan.

Sebagai salah satu contoh yang perlu ditempuh adalah memberikan kesempatan kepada masyarakat untuk memilih cara bagaimana mereka mau berpartisipasi dalam pembangunan. Disamping itu pemerintah desa harus mampu menjalankan kepemimpinan sesuai karakter masyarakatnya, dengan demikian akan terjalin adanya komunikasi dan kerjasama dalam pelaksanaan pembangunan.

Berdasarkan pada faktor-faktor yang mempengaruhi partisipasi masyarakat dalam pembangunan, dengan ini disarankan kepada pemerintah Kelurahan Palangka agar senantiasa memperbaiki dan mengejar pendidikan dalam segala modelnya. Disamping itu perlu pula diadakan pembinaan terhadap masyarakat yang mata pencahariannya sebagai petani sehingga mereka dapat hidup lebih layak lagi seperti kehidupan masyarakat pada umumnya.

\section{REFERENSI}

Bintoro, tjokramidjojo. 2006. Perencanaan daerah partisipatif, pondok edukasi, Pengantar analisis Kebijkan Negara. Jakarta : Rineka Cipta

David, Earton dan S.P Varma. 2009. Perencanaa Pembangunan. Jakarta : Gunung Agung.

Ghazali, Muhammad. 2008. Perencanaan Pembangunan Daerah : Strategi Menggali Potensi Dalam Mewujudkan Otonomi Daerah. Jakarta : PT Gramedia Pustaka utama.

Islamy, Irfan. 2007. Prinsip-prinsip perumusan kebijakan Negara, Bumi Aksara, Jakarta.

Keputusan Menteri dalam Negeri Nomor : 050187/kep/Bangda/2007 Tentang Pedoman 


Penilaian dan Evaluasi Pelaksanaan
Penyelenggaraan Musyawarah Perencanaan
Pembangunann (Musrenbang)

Kunarjo. 2002. Perencana dan Pengendalian program Pembangunan, Jakarta : Penerbit Universitas Indonesia, UI Press.

Lembaga Administrasi Negara $(2000,6)$ dan UndangUndang No. 32 tahun 2004 j.o Undang-Undang No. 12 Tahun 2008 tentang Pemerintahan Daerah.

Mohtar,M. 2002. Otonomi dan Pembangunan Derah. Jakarta: Erlangga

Sastropoetro. 2008. Partisipasi secara efektif. Jakarta : CV Cita Utama.

Suryono. 200I. Perencanaan Pembagunan Daerah Otonomi dan Pemberdayaan Masyarakat. Jakarta : CV Cita Utama.

Todaro. 2000. Perilaku Organisasi Konsep Dasar Dan Aplikasinya. Jakarta: Rajawali Grafindo Persada.

Undang-Undang No. 33 Tahun 2004 Tentang Sistem Perimbangan Keuangan Antara Pemerintah Pusat dan Daerah

Undang-undang Nomor 25 tahun 2004 tentang Sistem Perencanaan Pembangunan Nasional 109 